\title{
Perspective of the frontolateral craniotomies
}

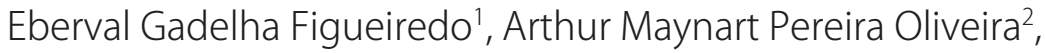 \\ José Píndaro P. Plese ${ }^{3}$, Manoel Jacobsen Teixeira ${ }^{4}$
}

\begin{abstract}
The pterional craniotomy is one of the most frequently surgical approaches used in neurosurgery and currently it has become a mainsteam. It allows excellent microsurgical exposure of anterior and posterior regions of the arterial circle of Willis, supra and paraselar regions, the superior orbital fissure of sphenoid bone, cavernous sinus, orbit, temporal lobe, midbrain and the frontal lobe. Like others techniques, the pterional craniotomy presented disadvantages related to dissection of the temporal muscle. From the first fronto lateral craniotomy described by Dandy to expose the optic chiasm and the pituitary we pass through the Yasargil's classical description of craniotomy centered in fronto-temporal sylvian fissure until reaching the recent"minipterional craniotomy", modifications of the pterional craniotomy were proposed to reduce the extra cranial tissue trauma and reduce the area of craniotomy without affecting the exposure of surgical targets, thus improving their aesthetic and functional results. An historical analysis of the frontolateral approaches has demonstrated that they have evolved from larger craniotomies to smaller ones, however only the minipterional craniotomy is able to offer similar surgical exposure.
\end{abstract}

Key words: craniotomy, minipterional craniotomy, neurosurgical procedures, pterional approach

\section{Perspectivas das craniotomias frontolaterais}

\section{RESUMO}

A craniotomia pterional é um dos acessos cirúrgicos mais freqüentemente utilizados. Esta técnica permite excelente exposição microcirúrgica das regiões anterior e posterior do polígono de Willis, regiões supra-selar, fissura orbital superior do osso esfenóide, seio cavernoso, órbita, lobo temporal, mesencéfalo e lobo frontal. Como outras técnicas, a craniotomia pterional tem desvantagens relacionadas à manipulação do músculo temporal. Desde a primeira craniotomia fronto lateral descrita por Dandy para expor o quiasma óptico e a hipófise, passando pela descrição clássica de Yasrgil para craniotomia centrada na fissura silviana, até chegar em craniotomias recentes como a"minipterional", modificações da craniotomia pterional foram propostas para reduzir o trauma do tecido extra craniano e reduzir a área da craniotomia sem afetar a exposição dos alvos cirúrgicos e melhorar seus resultados estéticos e funcionais. Uma análise histórica das abordagens frontolaterais demonstrou que elas evoluíram a partir de craniotomias maiores para menores, contudo somente a craniotomia minipterional oferece exposição cirúrgica similar à craniotomia pterional clássica. Palavras-chave: craniotomia, craniotomia minipterional, craniotomia pterional, procedimentos neurocirúrgicos.

\section{Correspondence \\ Eberval G. Figueiredo \\ Rua Oscar Freire 1399 / 171 \\ 05409-010 São Paulo SP- Brasil \\ E-mail: ebgadelha@yahoo.com}

Received 15 April 2009

Received in final form 4 August 2009

Accepted 13 August 2009
The pterional craniotomy is one of the most frequently surgical accesses used in neurosurgery and currently it has become a mainstream ${ }^{1-5}$. It allows excellent micro- surgical exposure of anterior and posterior regions of the arterial circle of Willis, supra and paraselar regions, the superior orbital fissure of sphenoid bone, cav- 


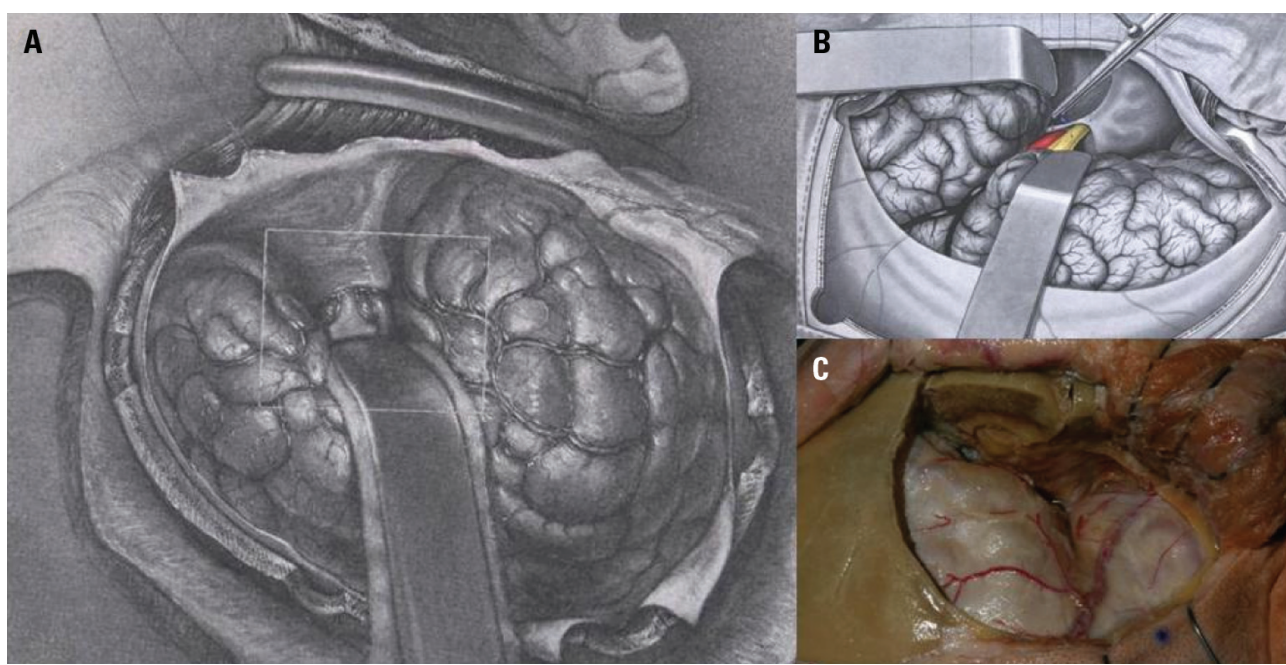

Fig 1. [A] Fronto-temporal-parietal craniotomy as recommended by Dandy. Source: Adapted from Dandy ${ }^{7}$. [B] Illustration showing the technique used by Kempe to access the arterial polygon of Willis and neighboring structures. Source: Adapted from Kempe ${ }^{8}, 1970$. [C] Photograph showing the pterional craniotomy as described by Yasargil et al. ${ }^{5}$.

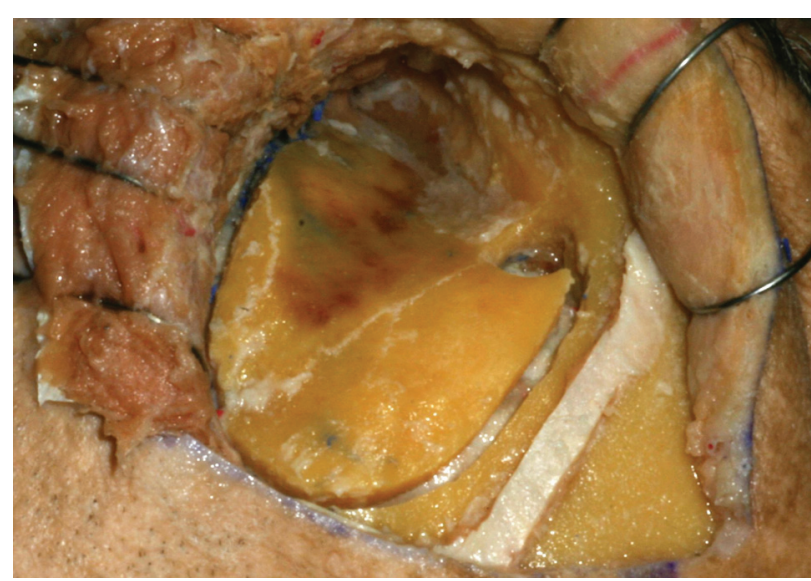

Fig 2. Photograph showing the pterional craniotomy as described by Figueiredo et al. ${ }^{5}$.

ernous sinus, the orbit, temporal lobe, midbrain and the frontal lobe $\mathrm{l}^{1,2,4,5}$

Its main disadvantage is a complete dissection of the temporal muscle, which causes poor aesthetic and functional outcomes ${ }^{1,3-5}$. It is the common occurrence of changes in cranio-facial contour due to injury of the frontal branch of the facial nerve and atrophy of the temporal muscle and subcutaneous fat pad $^{1,3-6}$.

Modifications of the pterional craniotomy were proposed to reduce the extra cranial tissue trauma and reduce the area of craniotomy without affecting the exposure of surgical targets, improving, thus, their aesthetic and functional results. Many of these innovations, however, do not provide adequate exposure of the anatomical structures and the aesthetic and functional results are unsatisfactory.
The genealogy of the pterional approach initiates in 1920 when Heuer and Dandy ${ }^{7}$ performed the first"pterional"or fronto-lateral craniotomy to expose the optic chiasm and pituitary. Dott in 1933 was the first to perform successful surgical treatment of cerebral aneurysms, however using subfrontal technique. Dandy ${ }^{7}$, devised a fronto-temporal craniotomy for treatment of aneurysms of the anterior circulation (Fig 1), with extensive exposure and retraction of the frontal lobe to allow access to the arterial circle of Willis ${ }^{7}$. This fronto-lateral approach was later refined by Kempe ${ }^{8}$. These changes aimed to provide wider exposure of the temporal lobe that was later retracted, after coagulation of basal temporal veins (Fig 1).

Yasargil et al. ${ }^{5}$ in 1975 proposed a craniotomy centered on the fronto-temporal sylvian fissure with less exposure of the frontal and temporal lobes. Compared with the technique proposed by Kempe, the approach described by Yasargil et al limited the extent of the craniotomy and added the removal of lateral two thirds of the lesser sphenoid wing, including the microsurgical dissection and opening of the sylvian fissure and cistern, with the objective of reducing the retraction of the frontal lobe (Fig 1). These technical innovations proposed by Yasargil et al. ${ }^{4-6}$ were responsible for the widespread use of pterional craniotomy due to the excellent surgical exposure provided.

Since then, several surgical techniques have been proposed to reduce the bone flap of the pterional craniotomy and reduce functional and aesthetic complications related ${ }^{9,10}$. The introduction of new surgical microscopes and improved lighting and magnification of the operative field of surgical anatomy made possible the use of less extensive and less invasive techniques. Advances in surgical 
technology and neuroanesthesia, allied to more detailed knowledge of microsurgical anatomy, increased the confidence of many neurosurgeons that now use a less extensive craniotomy $y^{9,10}$.

The advantages of this type of surgical approach include less operative time, less tissue trauma, the postoperative period more comfortable, less time of hospitalization, lower costs and better aesthetic and functional results ${ }^{10}$. However, these techniques do not allow adequate exposure of the surgical target and not necessarily reduce the extent of dissection of the temporal muscle ${ }^{9}$, and in addition offer no advantages when compared to the classical pterional craniotomy proposed by Yasargil et al. ${ }^{5}$.

In 1978, Brock and Dietzel ${ }^{9}$ suggested a subfrontal access through frontal craniotomy, with about $3.0 \mathrm{~cm}$ in their cranial-caudal axis, for the treatment of anterior circulation aneurysms of the arterial circle of Willis. In 1984, Suzuki et al suggested a fronto-temporal craniotomy with limitation of the removal of the temporal bone compared with the technique proposed by Yasargil et al. ${ }^{5,6}$. In 1992, Chehrazi proposed fronto-lateral craniotomy located entirely underneath the temporal muscle, the osteotomies includes part of the frontal bone, sphenoid, parietal and temporal and extends about $3.0 \mathrm{~cm}$ beyond ptério, which required extensive dissection of muscle temporal with functional and cosmetic implications.

In 1996, Harland et al., proposed craniotomy in which the skin incision ranges from 5.0 to $6.0 \mathrm{~cm}$, which is supplemented with a linear incision of the temporal muscle and a subjacent small craniectomy. This variant technique, however, does not provide adequate surgical exposure of the intracranial structures, and possibly does not change the unfavorable cosmetic results.

In 2004 Nathal et al. proposed technique very similar to that proposed by Harland et al but added drilling to the lower wing of the sphenoid boneincluding the anterior clinoid process. Even with these changes, there are limitations in surgical exposure of the target. Additionally, there is no objective data to confirm that the micro-anatomical exposure afforded by these techniques is comparable to that of conventional pterional technique.

The extent of the microsurgical dissection of the sylvian fissure and cistern needed to an adequate surgical exposure was not established until then. In 2006, Figueire- do et al. ${ }^{2}$ demonstrated that anatomical exposure is optimized when the microsurgical dissection of the sylvian fissure reach the ascending branch as the distal limit.

This dissection allowed better anatomical exposure of the arterial circle of Willis and reduced the need for cerebral retraction. The distal dissection offered no additional benefits for anatomical exposure of the arterial circle of Willis and adjacent anatomical structures ${ }^{2}$. Thus, a smaller craniotomy that has the ascending branch of the anterior sylvian fissure as distal and posterior limit, allows access to the arterial circle of Willis without compromising the surgical exposure of the targets on the pterional conventional technique. This new approach was termed the"minipterional craniotomy"(Fig 2) as it provides the same anatomical exposure as the conventional pterional technique.

An historical analysis of the frontolateral approaches has demonstrated that they have evolved from larger craniotomies to smaller ones. The greatest challenge of the modern neurosurgery is to minimize the approaches without compromising their anatomical exposures. Rather than using a"one-size fits all"craniotomy, the surgeon may tailor the approach based on the features of the lesion and the peculiarities of the surgical anatomy. This surgical strategy is certainly in the best interest of the surgical patients.

\section{REFERENCES}

1. Aydin IH, Takci E, Kadioglu HH, Kayaoglu CR, Tuzun Y. Pitfalls in the pterional approach to the parasellar area. Min Invas Neurosurg 1995;38:146-152.

2. Figueiredo EG, Deshmukh P, Zabramski JM, Preul MC, Crawford NR, Spetzler RF. The pterional-transsylvian approach: an analytical study. Neurosurgery 2006:59:263-269.

3. Vishteh AG, Marciano FF, David CA, Baskin JJ, Spetzler RF. The pterional approach. Operat Tech Neurosurg 1998;1:39-49.

4. Yasargil MG, Antic J, Laciga R, Jain KK, Hodosh RM, Smith RD. Micro- surgical pterional approach to aneurysms of the basilar bifurcation. Surg Neurol 1976;6:83-91.

5. Yasargil MG, Fox JL. The microsurgical approach to intracranial aneurysms. Surg Neurol 1975;3:7-14

6. Yasargil MG, Reichman MV, Kubik S. Preservation of the frontotemporal branch of the facial nerve using the interfascial temporalis flap for pterional craniotomy. Technical article. J Neurosurg 1987;67:463-466.

7. Dandy WE. The brain. Hagerstown: WF Prior, 1966.

8. Kempe LG. Operative neurosurgery. New York: Springer-Verlag, 1970

9. Brock M, Dietz $\mathrm{H}$. The small frontolateral approach for the microsurgical treatment of intracranial aneurysms. Neurochirurgia 1978;21:185-191.

10. van Lindert E, Perneczky 10. Paladino J, Pirker N, Stimac D, Stern-Padovan R Eyebrow keyhole approach in vascular neurosurgery. Min Invas Neurosurg 1998:41:200-203. 